\title{
Candida leandrae sp. nov., an asexual ascomycetous yeast species isolated from tropical plants
}

\author{
Carla C. C. Ruivo, ${ }^{1}$ Marc-André Lachance, ${ }^{2}$ Maurício Bacci Jr, ${ }^{1}$ \\ Solange C. Carreiro, ${ }^{1}$ Carlos A. Rosa ${ }^{3}$ and Fernando C. Pagnocca ${ }^{1}$ \\ ${ }^{1}$ Centro de Estudos de Insetos Sociais e Departamento de Bioquímica e Microbiologia, \\ Universidade Estadual Paulista - Unesp, CP 199, Rio Claro, SP, 13506-900, Brazil \\ ${ }^{2}$ Department of Biology, University of Western Ontario, London, Ontario, Canada N6A 5B7 \\ ${ }^{3}$ Departamento de Microbiologia - ICB, CP 486, Universidade Federal de Minas Gerais, Belo \\ Horizonte, MG, 31270-901, Brazil
}

\begin{abstract}
The novel yeast species Candida leandrae is described based on eight isolates from decaying fruits of Leandra reversa Cogn. (Melastomataceae) in an Atlantic rainforest site in Brazil, one from a Convolvulaceae flower in Costa Rica and one from a drosophilid in Hawai'i. The strains differed in their colony morphology, one being butyrous and smooth and the other being filamentous and rugose. Sequences of the D1/D2 domains of the large-subunit rRNA gene from both morphotypes were identical. $C$. leandrae belongs to the Kodamaea clade and is closely related to Candida restingae. The two species can be separated on the basis of growth at $37^{\circ} \mathrm{C}$ and the assimilation of melezitose, negative in the novel species. The type culture of C. leandrae is strain UNESP $00-64 R^{\top}\left(=\right.$ CBS $9735^{\top}=$ NRRL Y $\left.-27757^{\top}\right)$.
\end{abstract}

The Kodamaea clade (Rosa et al., 1999; Lachance et al., 1999) contains a growing number of interesting yeast species associated with plants (Lachance et al., 2001), mushrooms (Nakase et al., 1999) and associated insects. During a screening of yeasts associated with Atlantic rainforest fruits, an asporogenous species physiologically similar to Candida restingae was isolated from fruits of Leandra reversa Cogn. (Melastomataceae). The yeast presented two different colonial morphotypes, one being butyrous and smooth and the other being filamentous and rugose. Sequencing of the D1/D2 domains of the large-subunit rRNA gene indicated that the morphotypes are conspecific and confirmed a close relationship with $C$. restingae. In an independent study of the yeast community of Convolvulaceae flowers and associated insects in Hawai'i and Costa Rica, two additional strains with similar growth characteristics and D1/D2 sequences were recovered. We now describe the novel species as Candida leandrae.

\section{Yeast isolation and characterization}

C. leandrae strains were isolated independently from three localities. Eight strains were recovered from fruits of $L$. reversa (Melastomataceae). Ten fruits were collected in Picinguaba area, an Atlantic Rain Forest site at the 'Serra do Mar' State Park in São Paulo state, Brazil, during the

The GenBank/EMBL/DDBJ accession number for the large-subunit rRNA sequence of strain UNESP $00-64 R^{\top}$ is AY449659. summer of 2000. The fruits were individually blended in $2 \mathrm{ml}$ sterilized distilled water and $0 \cdot 1 \mathrm{ml}$ of the suspension was spread on YM agar ( $1 \%$ glucose, $0.5 \%$ peptone, $0.3 \%$ malt extract, $2 \%$ agar) containing $100 \mathrm{mg}$ chloramphenicol $1^{-1}$ (Trindade et al., 2002). Plates were incubated at $25^{\circ} \mathrm{C}$ for 3-5 days. Strain UWOPS 00-612b2 was recovered from Drosophila floricola collected in a flower of Ipomoea indica (Convolvulaceae) on the Island of Oahu, Hawai'i. The fly was captured aseptically and allowed to deposit yeast cells on the agar medium. Strain UWOPS 01-664c3 was isolated from a flower of Merremia tuberosa (Convolvulaceae), near Dos Rios, Guanacaste Province, Costa Rica. Flower scrapings were streak-inoculated on the agar medium. The plates were kept at room temperature until colonies were sufficiently differentiated. Representative yeast colonies were purified and maintained in YM slants or in liquid nitrogen. Yeasts were characterized by standard methods (Yarrow, 1998) and their identification was attempted using the keys of Kurtzman \& Fell (1998) and the CD-ROM Yeasts of the World (Boekhout et al., 2002).

\section{DNA sequence analysis}

Yeast DNA was extracted and purified according to a protocol recommended for the Genomic Prep. Cells and Tissue DNA Isolation kit (Amersham Pharmacia Biotech). The divergent D1/D2 domain (nucleotides 63-642 for Saccharomyces cerevisiae) at the $5^{\prime}$ end of the large-subunit rRNA gene was symmetrically amplified with primers 
NL-1 and NL-4 (O'Donnell, 1993). Each PCR was performed with the Ready-To-Go kit (Amersham Pharmacia Biotech) adding $1.5 \mu \mathrm{l}$ solution containing approximately $100 \mathrm{ng}$ DNA; $1.6 \mu \mathrm{l} \mathrm{NL}-1$ primer; $1.1 \mu \mathrm{l} \mathrm{NL}-4$ primer (6 pmol each) and 17.8 $\mu \mathrm{l}$ Milli-Q water. The sequence products were resolved in an ABI Prism 377 DNA sequencer (Applied Biosystems) at the Center for the Study of Social Insects - UNESP, Rio Claro, São Paulo, Brazil. Alternatively, the DNA was amplified directly from whole cells and sequenced as described by Lachance et al. (1999). The sequences were edited and aligned using CLUSTAL W 1.4 (Thompson et al., 1994) provided in the program DNAMAN 4.1 (Lynnon Biosoft, Vaudreuil, Québec, Canada), which was used also for construction of the neighbour-joining tree.

\section{Species delineation, classification and ecology}

The novel species $C$. leandrae formed two distinct colony morphotypes (Fig. 1). Six strains (UNESP 00-63L, 00-64L, 00-65L and 00-66L; UWOPS 00-612b2 and 01-664c3) formed butyrous and smooth colonies and four (UNESP $00-63 R, 00-64 R^{T}, 00-65 R$ and $00-66 R$ ) formed rugose and membranous colonies. The colony phenotypes were stable within each strain. The strains had nearly identical physiological profiles and the sequences of their D1/D2 largesubunit rRNA gene regions were identical. Sequence analysis further demonstrated that the species is related to $C$. restingae and belongs to the Kodamaea clade (Fig. 2). Extensive variability in colony morphology has been noted for Kodamaea kakaduensis (Lachance et al., 1999), Kodamaea anthophila and Kodamaea nitidulidarum, but not for C. restingae (Rosa et al., 1999). The D1/D2 sequences of $C$. leandrae and C. restingae differed by nine substitutions and three gaps in 467 bases, indicating that the two taxa represent phylogenetically distinct species. The isolates were examined after growth on most common sporulation media (5\% malt extract agar, cornmeal agar, Fowell acetate agar and dilute V8 agar), but asci were not formed. Mixed pairs showed no signs of conjugation, suggesting that $C$. leandrae occurs in nature in the asexual form.

Species in the Kodamaea clade have been isolated mostly

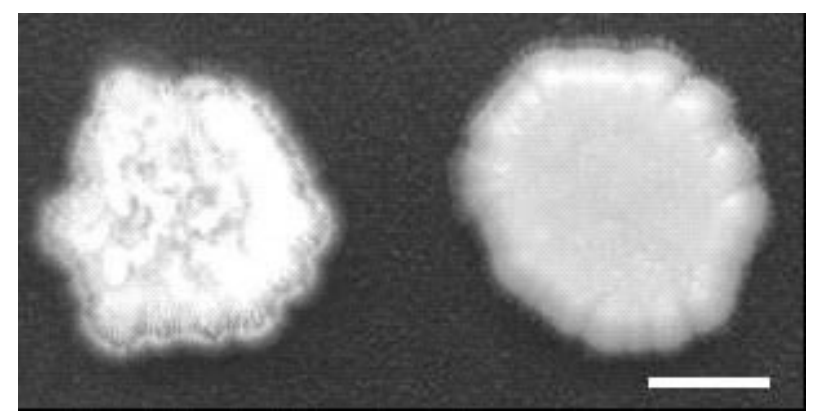

Fig. 1. Colonies of C. leandrae after 3 days on yeast extract/ malt extract agar. (Left) Rugose colony, strain UNESP 00-64R ${ }^{\top}$, and (right) smooth colony, strain UNESP 00-64L. Bar, $0.5 \mathrm{~mm}$.

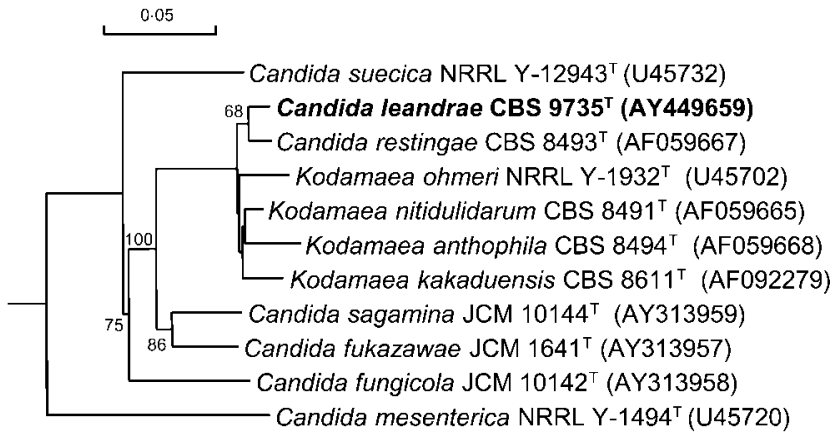

Fig. 2. Neighbour-joining phylogram based on the $D 1 / D 2$ divergent domains of the large-subunit rRNA gene of $C$. leandrae and related species. Percentage bootstrap values were obtained from 1000 replicates. Only values above $50 \%$ are shown. Bar, $5 \%$ sequence divergence.

from flowers and associated insects (Lachance et al., 2001). Kodamaea ohmeri has been recovered sporadically from a variety of substrates including flowers, insects or clinical specimens (Kurtzman, 1998; Rosa et al., 2003). Other species in the clade are associated with flowers and insects in tropical ecosystems (Rosa et al., 1999; Lachance et al., 1999, 2001), or with mushrooms (Nakase et al., 1999), where they are presumably vectored by fungivorous insects. $C$. restingae was isolated from cactus flowers in Brazil and from insects collected in a cactus flower in Costa Rica (Lachance et al., 2001). One strain was isolated from an unidentified fruit in an Atlantic Rain Forest site in Minas Gerais, Brazil. C. leandrae is probably associated with insects that visit decaying fruits and flowers in tropical ecosystems. Among several fruits collected in Picinguaba area, only decaying fruits of $L$. reversa yielded C. leandrae, suggesting a possible association with insects that exhibit a preference for that tree species. The very low frequency of recovery in hundreds of Convolvulaceae flowers or associated insects examined in Hawai'i and Costa Rica would suggest that the flowers and their insects are not a primary habitat of the species, but demonstrate its broad geographical distribution in the neotropics.

\section{Identification}

C. leandrae is easily distinguished from $C$. restingae based on the assimilation of inulin, growth on $50 \%$ glucose, and the absence of growth on melezitose, at $37^{\circ} \mathrm{C}$, or in the presence of $10 \% \mathrm{NaCl}$. These characters combined with the utilization of succinic acid and the lack of growth on melibiose allow separation from all other similar species. Confirmation of identity by D1/D2 sequencing is prudent.

\section{Latin diagnosis of Candida leandrae Ruivo, Pagnocca, Lachance et Rosa sp. nov.}

In medio liquido post dies tres ad $25^{\circ} \mathrm{C}$, cellulae ellipsoideae aut elongatae, singulae aut in catenis brevis $(2-4 \times 3-6 \mu \mathrm{m})$. 
Cultura in agaro extracta malti et levidinis continente post 4 dies ad $25^{\circ} \mathrm{C}$, candida, aliquando cum lineis radiabus, glabra aut rugosa, butyrosa aut firma. In agaro farinae Zea mays post dies 14 pseudomycelium formatur. Asci non formantur. Glucosum fermentatur. Glucosum, inulinum (interdum exigue), sucrosum, raffinosum (interdum exigue), galactosum, trehalosum, maltosum, methyl $\alpha$-D-glucosidium, L-sorbosum, D-xylosum (interdum lente), D-ribosum (variabile), ethanolum, glycerolum, ribitolum, xylitolum, mannitolum, glucitolum, acidum succinicum et acidum citricum (interdum exigue), acidum gluconicum (variabile), glucono$\delta$-lactonum, 2-ketogluconatum, $\mathrm{N}$-acetylglucosaminum, et n-hexadecanum (exigue) assimilantur. Non assimilantur melibiosum, lactosum, melezitosum, amylum solubile, cellobiosum (interdum exigue), salicinum (variabile), Lrhamnosum, L-arabinosum, D-arabinosum, methanolum, erythritolum, galactitolum, L-arabinitolum, meso-inositolum, acidum glucuronicum, acidum lacticum, 5-keto gluconatum et glucosaminum (variabile). Lysinum, ethylaminum et cadaverinum assimilantur at non natrium nitrosum nec natrium nitricum. Ad crescentiam vitaminae externae necessariae sunt. Augmentum in $35^{\circ} \mathrm{C}$, at non $37^{\circ} \mathrm{C}$. Materia amyloidea non formantur. Crescit in agaro extrato fermenti confecto 50 partes glucosi per centum. Non crescit in medio $100 \mu \mathrm{g} \mathrm{ml}^{-1}$ cycloeximido addito. Ureum non finditur. Diazonium caeruleum B negativum.
Habitat fructus Leandra reversa Cogn. (Melastomataceae) flores Convolvulacearum et insecta juncta. Typus stirps UNESP $00-64 \mathrm{R}^{\mathrm{T}}$. In collectione zymotica Centraalbureau voor Schimmelcultures, Trajectum ad Rhenum, sub no. CBS $9735^{\mathrm{T}}$, typus stirps deposita est.

\section{Description of Candida leandrae Ruivo, Pagnocca, Lachance \& Rosa sp. nov.}

Candida leandrae (le.an.d'rae. N.L. gen. n. leandrae of Leandra reversa).

In yeast extract $(0.5 \%)$ glucose $(2 \%)$ broth after 3 days at $25^{\circ} \mathrm{C}$, the cells are ellipsoidal to elongate $(2-4 \times 3-6 \mu \mathrm{m})$, occur singly, in budding pairs or in short chains (Fig. 3). On YM agar after 4 days at $25^{\circ} \mathrm{C}$, the colonies are white, convex, sometimes fringed, glabrous or membranous, smooth or rugose, butyrous to tough due to filamentous growth. After 2 weeks in Dalmau plate culture on cornmeal agar, a rudimentary pseudomycelium is formed. Asci are not formed on common sporulation media. Glucose fermentation is complete after 2 days to 2 weeks. Assimilation of carbon compounds: glucose, inulin (sometimes weak), sucrose, raffinose (sometimes weak), galactose, trehalose, maltose, methyl $\alpha$-D-glucoside, L-sorbose, Dxylose (sometimes slow), D-ribose (variable), ethanol, glycerol, ribitol, xylitol, D-mannitol, D-glucitol, succinic

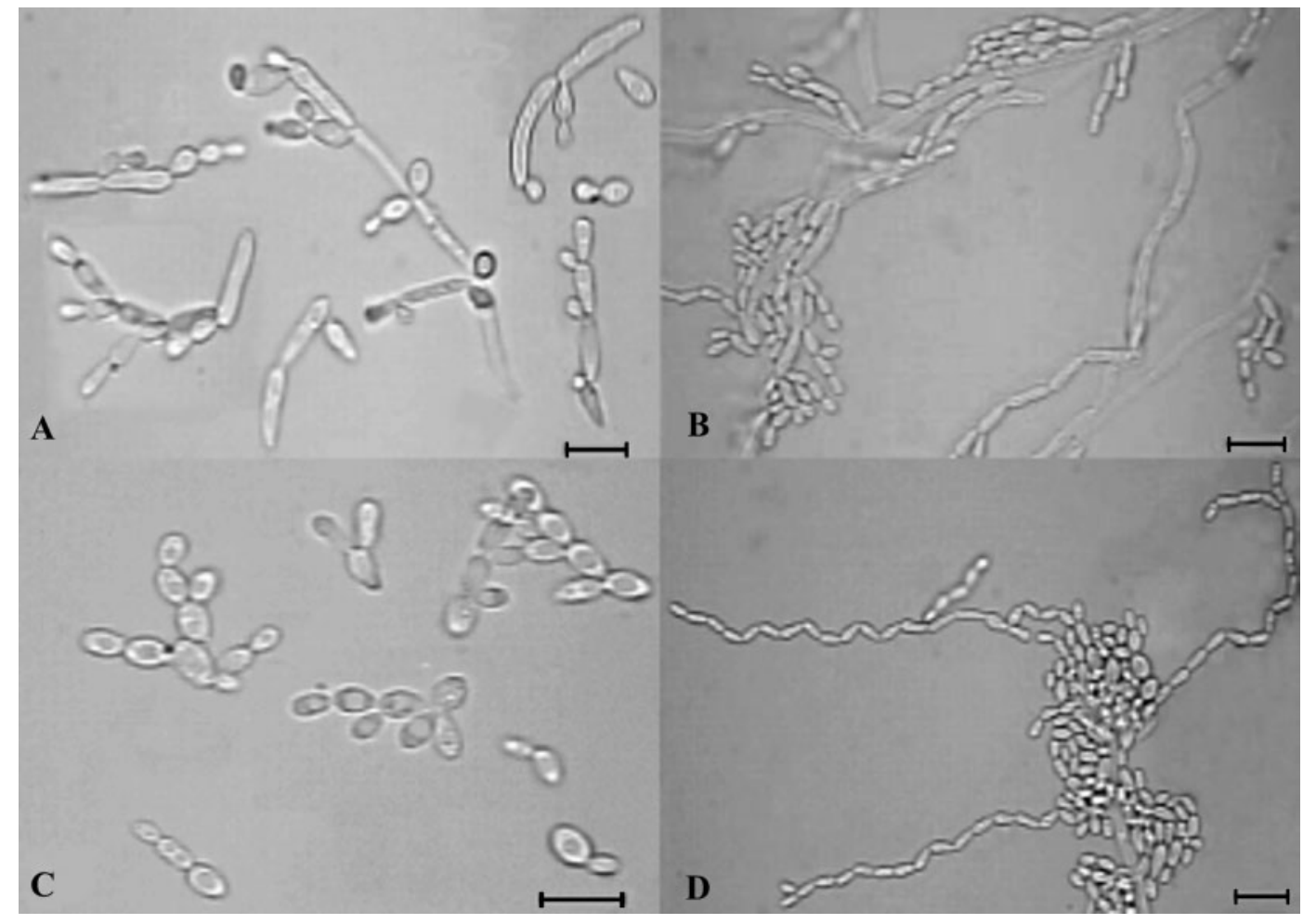

Fig. 3. Photomicrographs of cells of $C$. leandrae strain UNESP 00-64R (rugose colony) after (A) 3 days on $5 \%$ malt extract at $25^{\circ} \mathrm{C}$ and (B) 2 weeks on cornmeal agar at $25^{\circ} \mathrm{C}$. Cells of $\mathrm{C}$. leandrae strain UNESP 00-64L (smooth colony) after (C) 3 days on $5 \%$ malt extract at $25^{\circ} \mathrm{C}$ and (D) 2 weeks on cornmeal agar at $25^{\circ} \mathrm{C}$. Bars, $10 \mu \mathrm{m}$. 
acid, citric acid (sometimes weak), D-gluconic acid (variable), glucono- $\delta$-lactone, 2-ketogluconic acid, $\mathrm{N}$-acetylD-glucosamine and hexadecane (sometimes weak) are assimilated; no growth occurs on melibiose, lactose, melezitose, starch, cellobiose (occasionally weak), salicin (variable), L-rhamnose, L-arabinose, D-arabinose, methanol, erythritol, L-arabinitol, galactitol, myo-inositol, Dglucuronic acid, DL-lactic acid, 5-ketogluconic acid or D-glucosamine (variable). Assimilation of nitrogen compounds: L-lysine, ethylamine and cadaverine are positive; nitrate and nitrite are negative. Growth in vitamin-free medium is negative. Growth in amino acid-free medium is positive. Growth at $35^{\circ} \mathrm{C}$ is positive and at $37^{\circ} \mathrm{C}$ negative. Acid formation on chalk agar is slow, weak or absent. Urease activity and diazonium blue $\mathrm{B}$ reaction are negative. Production of amyloid compounds is negative. Growth on $50 \%$ glucose/yeast extract agar is positive. Growth on $\mathrm{YM}$ agar with $5 \% \mathrm{NaCl}$ is positive; $10 \% \mathrm{NaCl}$ negative. Growth in the presence of $0.01 \%$ cycloheximide is negative. Growth in the presence of $1 \%$ of acetic acid is negative.

The type culture is strain UNESP $00-64 \mathrm{R}^{\mathrm{T}}$. It was isolated from a decaying fruit of $L$. reversa in Brazil. It has been deposited in the collection of the Yeast Division of the Centraalbureau voor Schimmelcultures, Utrecht, the Netherlands, as strain CBS $9735^{\mathrm{T}}\left(=\mathrm{NRRL}\right.$ Y $\left.-27757^{\mathrm{T}}\right)$.

\section{Acknowledgements}

The authors thank the UNESP-CEIS for supporting this research project, and the Secretaria de Meio Ambiente (São Paulo State, Brazil) for allowing us to collect in the Picinguaba Nucleus at the 'Serra do Mar' State Park (Process. SMA: 42.364/99). We thank Dr Marco Antônio de Assis (Universidade Estadual Paulista - UNESP) for assistance in the collection and identification of plant species. The collecting efforts of J. M. Bowles and W. T. Starmer are gratefully acknowledged. Thanks are extended to M. Suzuki for the gift of type strains. We acknowledge financial support from the Coordenação de Aperfeiçoamento de Pessoal de Nível Superior (CAPES), the Conselho Nacional de Desenvolvimento Científico e Tecnológico $(\mathrm{CNPq})$ and the Natural Science and Engineering Research Council of Canada (M.-A. L.).

\section{References}

Boekhout, T., Robert, V., Smith, M. Th. \& 9 other authors (2002). Yeasts of the World. Morphology, Physiology, Sequences and Identification. Biodiversity Center of ETI, Multimedia Interactive Software. CD-ROM, Windows version 2.0. Heidelberg: Springer.

Kurtzman, C. P. (1998). Pichia E. C. Hansen emend. Kurtzman. In The Yeasts, a Taxonomic Study, 4th edn, pp. 273-352. Edited by C. P. Kurtzman \& J. W. Fell. Amsterdam: Elsevier.

Kurtzman, C. P. \& Fell, J. W. (editors) (1998). The Yeasts, a Taxonomic Study, 4th edn. Amsterdam: Elsevier.

Lachance, M.-A., Bowles, J. M., Starmer, W. T. \& Barker, J. S. F. (1999). Kodamaea kakaduensis and Candida tolerans, two new ascomycetous yeast species from Australian Hibiscus flowers. Can J Microbiol 45, 172-177.

Lachance, M.-A., Starmer, W. T., Rosa, C. A., Bowles, J. M., Barker, J. S. F. \& Janzen, D. H. (2001). Biogeography of the yeasts of ephemeral flowers and their insects. FEMS Yeast Res 1, 1-8.

Nakase, T., Suzuki, M., Sugita, T., Suh, S. O. \& Komagata, K. (1999). Three new species of anamorphic yeasts phenotypically and phylogenetically related to Candida mesenterica: the description of Candida fungicola sp. nov., Candida sagamina sp. nov., and Candida fukazawae sp. nov. isolated from fruit bodies of mushrooms. Mycoscience 40, 465-476.

O'Donnell, K. (1993). Fusarium and its near relatives. In The Fungal Holomorph: Mitotic and Pleomorphic Speciation in Fungal Systematics, pp. 225-233. Edited by D. R. Reynolds \& J. W. Taylor. Wallingford: CAB International.

Rosa, C. A., Lachance, M.-A., Starmer, W. T., Barker, J. S. F., Bowles, J. M. \& Schlag-Edler, B. (1999). Kodamaea nitidulidarum, Candida restingae and Kodamaea anthophila, three new related yeast species from ephemeral flowers. Int J Syst Bacteriol 49, 309-318.

Rosa, C. A., Lachance, M.-A., Silva, J. O. C., Teixeira, A. C. P., Marini, M. M., Antonini, Y. \& Martins, R. P. (2003). Yeast communities associated with stingless bees. FEMS Yeast Res 4, 271-275.

Thompson, J. D., Higgins, D. G. \& Gibson, T. J. (1994). CLUSTAL W: improving the sensitivity of progressive multiple sequence alignment through sequence weighting, position-specific gap penalties and weight matrix choice. Nucleic Acids Res 22, 4673-4680.

Trindade, R. C., Resende, M. A., Silva, C. M. \& Rosa, C. A. (2002). Yeasts associated with fresh and frozen pulps of Brazilian tropical fruits. Syst Appl Microbiol 25, 294-300.

Yarrow, D. (1998). Methods for the isolation and identification of yeasts. In The Yeasts, a Taxonomic Study, 4th edn, pp. 77-100. Edited by C. P. Kurtzman \& J. W. Fell. Amsterdam: Elsevier. 